University of South Florida

DIGITAL COMMONS

Digital Commons @ University of

@ UNIVERSITY OF SOUTH FLORIDA

South Florida

8-24-2004

\title{
Lithium Abundance and Isotope Systematics of Forearc Serpentinites, Conical Seamount, Mariana Forearc: Insights Into the Mechanics of Slab-Mantle Exchange During Subduction
}

\author{
Laurie D. Benton \\ Carnegie Institution of Washington \\ Jeffrey G. Ryan \\ University of South Florida, ryan@usf.edu \\ Ivan P. Savov \\ University of South Florida, savovi@si.edu
}

Follow this and additional works at: https://digitalcommons.usf.edu/gly_facpub

Part of the Geochemistry Commons, Geology Commons, and the Geophysics and Seismology

Commons

\section{Scholar Commons Citation}

Benton, Laurie D.; Ryan, Jeffrey G.; and Savov, Ivan P., "Lithium Abundance and Isotope Systematics of Forearc Serpentinites, Conical Seamount, Mariana Forearc: Insights Into the Mechanics of Slab-Mantle Exchange During Subduction" (2004). Geology Faculty Publications. 3.

https://digitalcommons.usf.edu/gly_facpub/3

This Article is brought to you for free and open access by the Geology at Digital Commons @ University of South Florida. It has been accepted for inclusion in Geology Faculty Publications by an authorized administrator of Digital Commons@ University of South Florida. For more information, please contact digitalcommons@usf.edu. 


\title{
Lithium abundance and isotope systematics of forearc serpentinites, Conical Seamount, Mariana forearc: Insights into the mechanics of slab-mantle exchange during subduction
}

\author{
Laurie D. Benton \\ Department of Terrestrial Magnetism, Carnegie Institution of Washington, 5241 Broad Branch Road, NW, \\ Washington, D.C. 20015, USA \\ Exponent Environmental Group, 15375 30th Place, Suite 250, Bellevue, Washington 98007, USA \\ (lbenton@exponent.com) \\ Jeffrey G. Ryan \\ Department of Terrestrial Magnetism, Carnegie Institution of Washington, 5241 Broad Branch Road, NW, \\ Washington, D.C. 20015, USA \\ Department of Geology, University of South Florida, 4202 East Fowler Avenue, SCA 528, Tampa, Florida \\ 33620-5201, USA (ryan@chuma.cas.usf.edu)
}

Temporarily at Division of Undergraduate Education, National Science Foundation, 4201 Wilson Boulevard, Arlington, Virginia 22230, USA

\section{Ivan P. Savov}

Department of Geology, University of South Florida, 4202 East Fowler Avenue, SCA 528, Tampa, Florida 33620-5201, USA (savovip@yahoo.com)

[1] Variable lithium contents and contrasting Li isotopic signatures are evident in the serpentininite muds and clasts extruded at Conical Seamount in the Mariana forearc. The muds have high Li contents compared to mantle values $(3-7 \mathrm{ppm})$ and a mean $\delta^{7} \mathrm{Li}$ value of $\sim+6 \%$. The clasts are generally lower in $\mathrm{Li}$, and $\delta^{7} \mathrm{Li}$ varies from $-6 \%$ to $+10 \%$, with higher $\delta^{7} \mathrm{Li}$ correlating broadly to higher lithium contents. The diverse $\delta^{7} \mathrm{Li}$ in the serpentinite clasts suggests $\mathrm{Li}$ exchanges between mantle rocks and evolving slab-derived fluids from different depths, producing a subarc mantle that is zoned in terms of $\mathrm{Li}$ abundances and $\delta^{7} \mathrm{Li}$. Mariana forearc Li isotopic signatures reach values as high as those reported in Mariana arc lavas, but neither Mariana lavas nor lavas from other "mature" arcs show the variability observed in the serpentinites. Although elevated serpentinite Li contents indicate forearc releases of $\mathrm{Li}$, large differences in $\delta$ Li are not evident in the slab outputs at forearc versus arc depths in the Marianas, despite evidence for changes in other alkaline species (e.g., Ba, Sr, K). It is thus possible that the Li sampled by Mariana arc volcanoes is in large part Li which was released in the forearc and transported in the mantle via convection to arc depths, as has been proposed to explain B isotopic variations [Straub and Layne, 2002]. The uniform $\delta^{7} \mathrm{Li}$ signatures observed in "mature" volcanic arcs [Tomascak et al., 2002] are consistent with higher overall fluxes of slab fluids, which generate larger melting anomalies, including both modified and nonmodified mantle wedge domains. High or low $\delta^{7} \mathrm{Li}$ in lavas from anomalous arcs (e.g., Panama [Tomascak et al., 2000]) may indicate that the volumes of mantle sampled in these magmatic events are smaller and thus more likely to reflect the signatures of hydrated "plums" [e.g., Allègre and Turcotte, 1986; Phipps Morgan and Morgan, 1999] with extremely high or low $\delta^{7} \mathrm{Li}$. 
Components: 7951 words, 9 figures, 1 table.

Keywords: lithium; forearcs; isotope ratios; Mariana; serpentine; subduction.

Index Terms: 1010 Geochemistry: Chemical evolution; 1040 Geochemistry: Isotopic composition/chemistry; 1025 Geochemistry: Composition of the mantle.

Received 1 February 2004; Revised 23 May 2004; Accepted 7 July 2004; Published 24 August 2004.

Benton, L. D., J. G. Ryan, and I. P. Savov (2004), Lithium abundance and isotope systematics of forearc serpentinites, Conical Seamount, Mariana forearc: Insights into the mechanics of slab-mantle exchange during subduction, Geochem. Geophys. Geosyst., 5, Q08J12, doi:10.1029/2004GC000708.

Theme: Trench to Subarc: Diagenetic and Metamorphic Mass Flux in Subduction Zones Guest Editors: Gary Bebout, Jonathan Martin, and Tim Elliott

\section{Introduction}

[2] The "slab input" to the mantle sources of arc lavas is a chemically complex flux within which a number of components have been identified: melts of subducted sediment [Plank and Langmuir, 1993; Elliott et al., 1997], fluids from basaltic crust [Miller et al., 1994; Ishikawa and Nakamura, 1994; Class et al., 2000], melts of basaltic crust [Kepezhinskas and Defant, 1996] and fluids derived from subducted sediment [Class et al., 2000]. While these different components can be recognized on discrimination diagrams, it is difficult to quantify their relative roles, as we have no physical or geochemical descriptions of them; i.e., if a fluid from sediment is involved, what is the overall makeup of this fluid phase (i.e., proportions of $\mathrm{H}_{2} \mathrm{O}, \mathrm{CO}_{2}, \mathrm{SO}_{2}$, halogens; $\mathrm{pH} ; \mathrm{f}_{\mathrm{O} 2}$ ) and what elements and/or chemical species does it transport at the depths of arc volcanic root zones? In the Mariana subduction system we have an opportunity to assess one particular slab outflux: an $\mathrm{H}_{2} \mathrm{O}-$ dominated fluid release at low temperatures, which is absorbed into the mantle wedge via serpentinization reactions, and is thus measurable through analysis of the diapiric serpentinites erupting in the outer forearc region of the Mariana arc. This flux has been shown to mobilize a limited menu of "fluid mobile" species, which, interestingly, do not include elements such as $\mathrm{Ba}$ and $\mathrm{U}$, that are normally used to fingerprint slab influences [Pearce and Peate, 1995; Elliott et al., 1997; see also Savov et al., 2000, 2002; Morris and Ryan, 2003].

[3] Lithium is an element that appears to be mobile in forearc settings, and it is unique among mobile elements in that it partitions well into olivine and other Mg silicates [Ryan and Langmuir, 1987; Brenan et al., 1998a, 1998b; Seitz and Woodland, 2000]. Lithium abundance and isotope systematics may thus be able to provide a more detailed picture of how slab fluids interact with the mantle in forearc settings. Lithium isotopes show strong fractionations during solid-fluid exchanges due to the large mass difference between ${ }^{6} \mathrm{Li}$ and ${ }^{7} \mathrm{Li}[\mathrm{e} . \mathrm{g}$., Chan and Edmond, 1988], and should thus allow us to assess how Li is moved from slab to mantle at arc or forearc depths. We report below on $\mathrm{Li}$ abundance and $\mathrm{Li}$ isotope data collected on serpentinite muds and serpentinized ultramafic rocks from the Conical Seamount, an active serpentinite mud volcano situated $\sim 29 \mathrm{~km}$ above the downgoing slab in the Mariana forearc [Fryer, 1992].

\section{Geologic Setting and Sample Selection}

[4] The Conical Seamount lies at approximately $19^{\circ} 31^{\prime} \mathrm{N}$ Latitude, $146^{\circ} 40^{\prime} \mathrm{W}$ Longitude, at $\sim 3000 \mathrm{~m}$ water depth, $\sim 90 \mathrm{~km}$ inboard of the Mariana trench (Figure 1). All the forearc seamounts of the Mariana subduction system lie within zones of extensional faulting which run perpendicular to the strike of the trench. The seamount consists of sequences of serpentinite mudflows, and these flows include entrained clasts of highly serpentinized harzburgites and dunites [Hussong and Fryer, 1985; Fryer et al., 1990; Fryer, 1992, 2002]. Mudflow activity is driven by the upwelling of an evolved, highly alkaline ( $\mathrm{pH} 12.6$ ), low-chlorinity (less than half that of seawater) pore fluid that originates from the dehydration of the subducting slab and is responsible for serpentinization reactions at depth. This fluid, sampled as pore waters in 

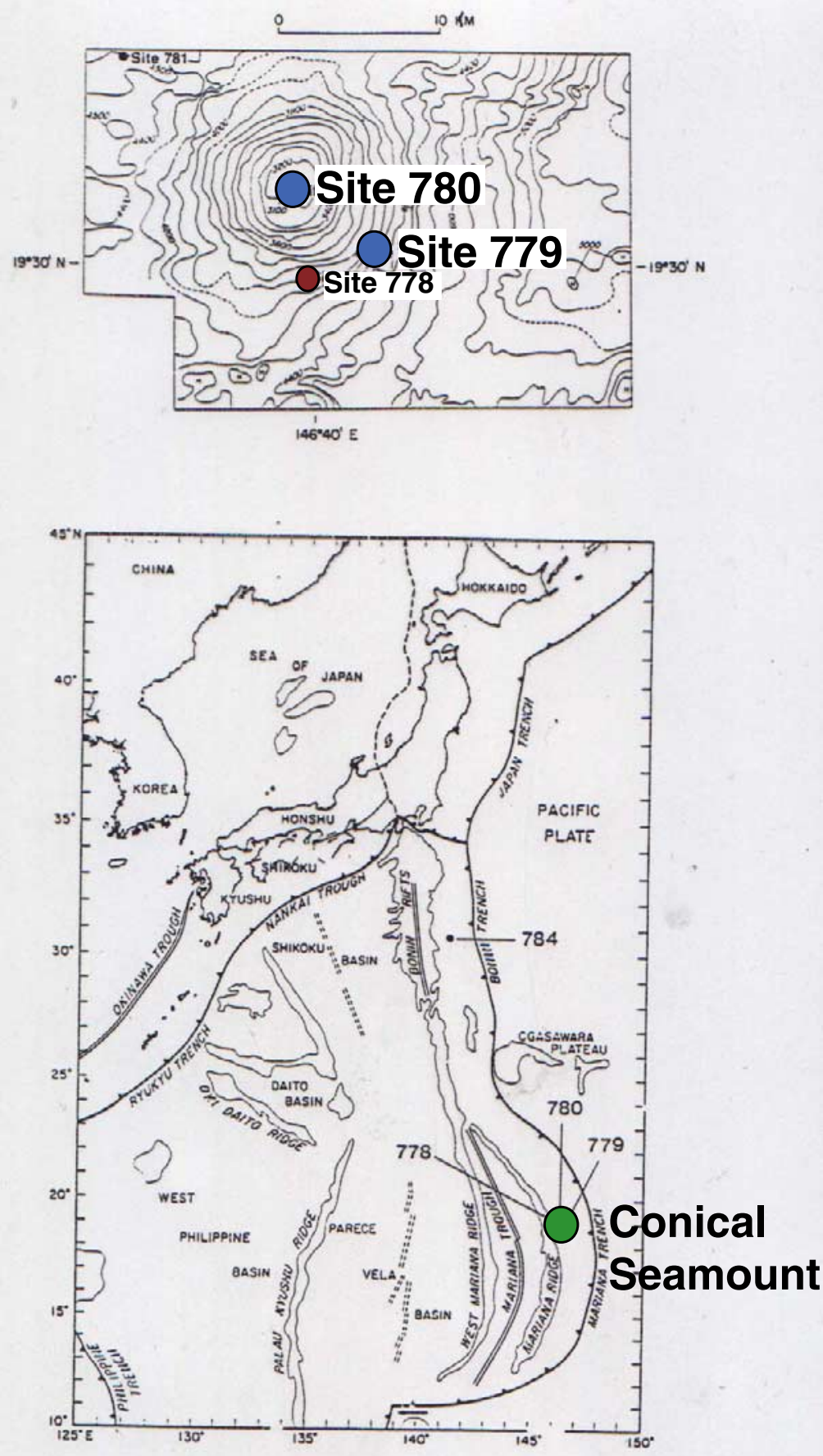

Figure 1. Map of the Mariana forearc region, with close-up of the Conical Seamount showing the location of Sites 779 and 780. From Fryer [1992].

the uppermost portion of the seamount (1300 meters below seafloor (mbsf)), also has distinctive trace element signatures, including highly elevated B concentrations ( $\sim 42 \mathrm{ppm}$, $\sim 10 \mathrm{x}$ seawater) and $\mathrm{Li}$ contents (at $\sim 11 \mathrm{ppb}$ ) that are more than three orders of magnitude lower than seawater [Fryer et al., 1985; Fryer and Fryer, 1987; Mottl, 1992; Mottl et al., 2003]. 
[5] During the Ocean Drilling Program (ODP) Leg 125, three sites on Conical Seamount were drilled: the summit (Site 780) and two flank sites (Sites 778 and 779; Figure 1 inset). Drill core from Holes 780C and 779A provide the longest sequences of serpentinite muds and clasts, and also include fragments of basaltic crustal rocks, as well as small pieces of blueschist-facies meta-mafic rocks which are probably derived from the downgoing plate [Fryer and Fryer, 1987; Fryer, 1992; Maekawa et al., 1992, 1995]. Serpentinites (i.e., clasts and matrix collectively unless specified otherwise) from Site 780 are in intimate association with anomalous pore waters to within $3 \mathrm{~m}$ of the seafloor. Serpentinites from Site 779 are in contact with higher chlorinity pore waters, which show evidence for exchange with seawater, but preserve the high $\mathrm{pH}$ characteristics of the upwelling fluid at depths below $~ 100$ mbsf [Fryer, 1992; Mottl, 1992].

[6] Samples of the serpentinite muds were selected to examine the $\mathrm{Li}$ and $\mathrm{Li}$ isotope systematics of the evolving, slab-derived fluid, as data for B isotopes and other tracers suggest that the muds are in chemical equilibrium with the pore waters [Benton et al., 2001; Haggerty, 1991; Haggerty and Chaudhuri, 1992; Mottl, 1992; Mottl et al., 2003]. Samples of the entrained ultramafic clasts were examined in search of deeper-seated Li isotopic signatures, which might be more representative of conditions closer to the slab-mantle interface. Most of our samples are highly serpentinized $(>60 \%$ serpentine) with loss on ignition (LOI) values between $8 \%$ and $24 \%$. As $\mathrm{pH}, \mathrm{Sr}$ isotope, and $\mathrm{B}$ isotope results indicate the influence of infiltrating seawater in shallow portions of Sites 779 and 780 (see above), we focused our sampling on deeper segments of cores, and followed the same protocols for sample selection and preparation as had been used for B isotopes (see below). As was the case with $\mathrm{B}$ and $\mathrm{B}$ isotopes, $\mathrm{Li}$ concentrations and $\mathrm{Li}$ isotope ratios appear unaffected by seawater in the deeper core segments at both sites. Shallower core sections show $\mathrm{Li}$ concentration and $\mathrm{Li}$ isotope variations similar to those found deeper, suggesting that overall, the influence of seawater may be negligible.

\section{Methods}

[7] We chose samples for analysis from both Site 779 (Holes A and B) and Site 780 (Holes C and D; Figure 1). Clast samples were selected from the interiors of relatively vein-free core segments, on the presumption that the interiors are less likely to suffer late-stage exchanges with seawater. However, it turned out to be impossible to avoid finer veins, so many of our samples included veined materials. Both the matrix and clast samples consisted of chrysotile \pm lizardite or antigorite [Mottl, 1992; Fryer, 1992; Heling and Schwarz, 1992; Lagabrielle et al., 1992; Saboda et al., 1992]. Matrix samples were ground with an agate mortar and pestle and then washed with deionized water to remove salts from pore waters [Spivack and Edmond, 1987]. Clast samples were crushed, washed in deionized water, and powdered in a ball mill using an alumina vial dedicated to serpentinite samples.

[8] Samples analyzed for $\mathrm{Li}$ abundances were dissolved using an $\mathrm{HF}: \mathrm{HClO}_{4}$ digestion technique, and analyzed by standard additions methods via Direct Current Plasma emission spectrometry (DCP) (see Ryan and Langmuir [1987] for details on the method). A subset of the samples was analyzed for Li by isotope dilution mass spectrometry (IDMS) (see Table 1). Agreement between DCP and IDMS Li data is within the $\pm 5 \%$ precision of the DCP analyses.

[9] Samples for Li isotope determinations were prepared via an $\mathrm{HF}: \mathrm{HNO}_{3}: \mathrm{HClO}_{4}$ digestion, followed by a final dry-down in concentrated $\mathrm{HNO}_{3}$, which was necessary to decompose abundant $\mathrm{Mg}\left(\mathrm{ClO}_{4}\right)_{2}$ generated in the breakdown of these $\mathrm{Mg}$-rich rocks. Mg-perchlorates have a limited solubility in the $0.66 \mathrm{M} \mathrm{HNO}_{3} / 33 \%$ methanol solutions loaded onto cation columns for Li elution, and could be observed as an immiscible liquid when present. Lithium isotope measurements on samples with $\mathrm{Mg}$ perchlorate residues were anomalously high, suggesting some fractionation of the isotopes occurred when it was present. The addition of strong $\mathrm{HNO}_{3}$ followed by a hard dry-down at $\sim 160^{\circ} \mathrm{C}$ resulted in clear solutions for all such samples, though in a few cases multiple dry-downs were necessary to decompose all of the $\mathrm{Mg}$-perchlorates.

[10] For isotopic analysis, Li was isolated by ion-exchange chromatography using the methanol$\mathrm{HNO}_{3}$ method described by Tomascak et al. [1999a], and the final solutions were diluted to $\sim 100 \mathrm{ng} \mathrm{Li} / \mathrm{ml}$ for analysis. Lithium isotope measurements were made on the VG P-54 multiple-collector magnetic sector ICP-MS at the Department of Terrestrial Magnetism according to procedures outlined by Tomascak et al. [1999b]. Each sample was measured a minimum of three times, and the measurements were averaged. Duplicates of several of our samples were prepared and analyzed as a further check on precision (see Table 1). On the basis of the total 
Table 1. Lithium Abundance and Isotope Data for Conical Seamount Samples

\begin{tabular}{lccc}
\hline Sample Identification $^{\mathrm{a}}$ & Depth, mbsf & ${ }^{7} \mathrm{Li}, \%$ o & Li, ppm \\
\hline \multicolumn{4}{c}{ Serpentinite Matrix } \\
125-779A- & & \\
05R-3, 054-056 & 32.75 & +6.3 & \\
13R-1, 138-140 & 107.45 & & 1.80 \\
18R-2, 087-089 & 157.38 & +7.2 & 0.76 \\
28R-2, 112-114 & 227.60 & & 1.47 \\
32R-2, 000-010 & 265.95 & & 1.04 \\
36R-2, 132-134 & 305.85 & +4.6 & 26.4 \\
125-779B- & & & \\
01R-1, 117-119 & 1.18 & +4.9 & 3.83 \\
125-780C- & & & \\
02R-1, 002-004 & 5.53 & +7.3 & 4.59 \\
04R-1, 024-026 & 23.74 & +6.2 & 4.66 \\
05R-1, 037-039 & 33.37 & +5.7 & 4.18 \\
07R-1, 014-017 & 52.24 & +4.3 & 2.89 \\
12R-1, 006-008 & 100.26 & +6.9 & 4.27 \\
13R-1, 053-055 & 107.03 & +5.2 & 2.23 \\
15R-1, 027-029 & 125.77 & +7.0 & 7.58 \\
16R-1, 033-035 & 135.33 & +6.8 & 5.83 \\
18R-1, 129-131 & 155.29 & +6.6 & 7.07 \\
18R-1, 138-140 & 155.38 & +7.3 & 6.55 \\
duplicate & & +7.5 & \\
125-780D- & & & \\
01X-1, 026-028 & 0.26 & +6.3 & 7.05 \\
duplicate & & +5.9 & \\
02X-1, 035-037 & 2.85 & +6.6 & 5.63 \\
06X-2, 033-035 & 21.51 & +7.1 & 7.52 \\
07X-5, 123-125 & 29.31 & +6.6 & 6.61 \\
& & &
\end{tabular}

Serpentinized Peridotite Clasts

$\begin{array}{lrrr}\text { 125-779A- } & & & \\ \text { 03R-CC, 015-016 } & 10.76 & +10.3 & 10.5 \\ \text { duplicate } & & +9.5 & \\ \text { 06R-1, 020-022 } & 39.22 & +3.6 & 9.63 \\ \text { 08R-1, 090-093 } & 59.43 & +2.8 & 3.31 \\ \text { 11R-1, 016-018 } & 87.48 & -1.3 & 3.45 \\ \text { duplicate } & & -1.3 & \\ \text { 13R-2, 053-054 } & 108.64 & +1.9 & 2.71 \\ \text { 15R-2, 022-023 } & 126.63 & +2.0 & 8.43 \\ \text { 17R-3, 123-125 } & 149.45 & +5.0 & 3.36 \\ \text { 20R-1, 017-018 } & 169.28 & +10.2 & 12.9 \\ \text { duplicate } & & +8.1 & \\ \text { 22R-2, 020-022 } & 171.81 & +6.4 & 4.35 \\ \text { 25R-1, 029-030 } & 197.10 & +7.2 & 3.46 \\ \text { 28R-3, 029-030 } & 229.10 & +7.3 & 2.79 \\ \text { 31R-1, 057-058 } & 255.28 & +3.1 & 2.71 \\ \text { duplicate } & & +3.0 & \\ \text { 33R-2, 082-083 } & 276.33 & +6.0 & 1.59 \\ \text { 35R-1, 113-114 } & 294.44 & +4.0 & 5.65 \\ \text { 125-780C } & & & \\ \text { 03R-1, 3A } & 14.30 & +3.5 & 18.9 \\ \text { 06R-1, 7A } & 43.10 & +1.1 & 3.21 \\ \text { 08R-1, 5 } & 61.95 & +0.62 & 1.93 \\ \text { 09R-1, 6 } & 71.60 & -6.1 & 1.63 \\ \text { 10R-1, 2 } & 80.90 & +1.6 & 4.73 \\ \text { 12R-1, 2 } & 100.40 & +5.7 & 16.2 \\ \text { 13R-1, 7 } & 106.90 & +3.6 & 9.43 \\ \text { 16R-1, 7 } & 135.55 & -0.8 & 4.18 \\ \text { 18R-1, 055-057 } & 154.55 & -3.6 & 2.66 \\ \text { 18R-1, 2B } & 155.20 & -2.4 & 4.53\end{array}$

Table 1. (continued)

\begin{tabular}{lrrr}
\hline Sample Identification $^{\mathrm{a}}$ & Depth, mbsf & $\delta^{7} \mathrm{Li}, \%$ o & $\mathrm{Li}, \mathrm{ppm}$ \\
\hline \multicolumn{4}{c}{ Reference Materials } \\
UB-N serpentinite & -2.6 & $27^{\mathrm{b}}$ \\
JDF-D2 (MORB) & +6.8 & 7.8 \\
\hline
\end{tabular}

\footnotetext{
${ }^{\mathrm{a}}$ Sample identification is according to the following ODP convention: 125 (ODP Leg) - 779 (Site) A (Hole) - 05 (Core) R (drilling method, e.g., $\mathrm{R}$ for rotary and $\mathrm{X}$ for extended core barrel) - 3 (Section), 054-056 cm (Interval).

${ }^{\mathrm{b}}$ Value from International Association of Geoanalysts Web site (http://www.geoanalyst.org).
}

errors of our sample measurements, and duplicate analyses of samples, our precision was at least as good as the $\pm 1 \%$ o $(2 \sigma)$ level reported for the ICPMS method in the past [e.g., Tomascak et al., 1999b, 2000].

\section{Results}

[11] Lithium abundance and $\mathrm{Li}$ isotope data for the Conical Seamount and relevant reference samples are presented in Table 1. Lithium concentrations in the serpentinized ultramafic clasts are quite variable, ranging from $0.9-18.9 \mathrm{ppm}$. The serpentinite matrix samples range from $1-8 \mathrm{ppm} \mathrm{Li} \mathrm{(with} \mathrm{one}$ outlier at $26.3 \mathrm{ppm}$ ), and are less variable in $\mathrm{Li}$ content (Figure 2). Lithium contents in Site 779 matrix samples appear to be lower than those from Site 780 (1-4 ppm versus 4-8 ppm, respectively; Figure 2). The very high $\mathrm{Li}$ concentration in sample 779A-36R-2, 132-134, the deepest sample analyzed (306 mbsf), probably cannot be generated purely via equilibrium exchange of serpentine with the associated, higher Li pore waters $(0.2-0.8 \mathrm{ppm}$ Li, higher than seawater [see Mottl, 1992]), especially given the low $\mathrm{Li}$ contents of other mud samples in contact with these fluids. The Li content in this sample may thus reflect the admixture of fine-grained mafic materials with higher Li and/or a higher affinity for Li during solid/fluid exchange [Benton, 1997; see also Guggino et al., 2002; Savov, 2004].

[12] Lithium concentrations show no clear relationship to LOI in our samples, or to the abundances of other fluid-mobile, incompatible trace elements (Figure 3). The serpentinite matrix samples show a general positive variation relative to boron contents, but with several outliers at very high $\mathrm{B}$ or $\mathrm{Li}$ abundances. The cause for this diversity may be that, as noted above, mud samples may contain variable amounts of fine grained, altered mafic material (either blueschist-grade crustal material from the slab, or material from the overriding 


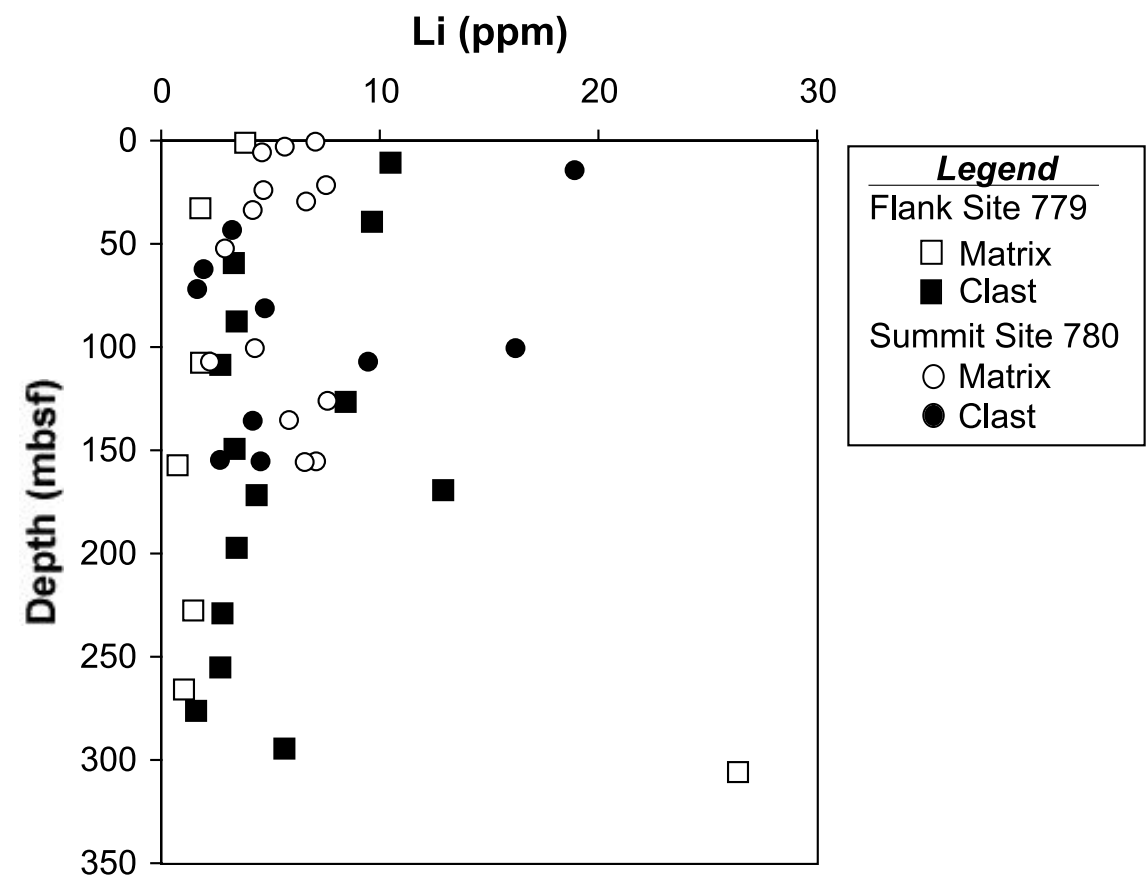

Figure 2. Plot of Li concentrations for Leg 125 serpentinites versus depth in core. Matrix and clast samples from each drill site are as noted on the diagram; matrix samples are open symbols, and clast samples are solid symbols.

crust), which could affect the systematics of these elements differently [Benton, 1997; Guggino et al., 2002; Savov, 2004].

[13] $\mathrm{Li}$ isotopic variations in the clasts and muds contrast markedly. The serpentinite muds span a limited range of $\delta^{7} \mathrm{Li}(+4$ to $+8 \%$ ), with a mean value near $+6 \%$. The serpentinized clasts vary widely in $\delta^{7} \mathrm{Li}$, from $-6 \%$ to $+10 \%$ (Figure 4 ). This variation is not related to LOI or abundances of other mobile elements (Figure 5), but does show a broad relationship to Li content, with the higher $\mathrm{Li}$ clasts associated with generally higher $\delta^{7} \mathrm{Li}$ values, and those samples with $\mathrm{Li}$ contents $<5 \mathrm{ppm}$ covering nearly the entire range of $\delta^{7} \mathrm{Li}$ values observed (Figure 6).

\section{Discussion}

\subsection{Origins of $\mathrm{Li}$ Distribution and $\delta^{7} \mathrm{Li}$ Signatures in Conical Serpentinites}

[14] Lithium concentrations in the Leg 125 serpentinites are generally elevated relative to their harzburgite or dunite protoliths [Ryan and Langmuir, 1987; Seitz and Woodland, 2000]. Interestingly, Li abundances are quite variable in the Leg 125 samples analyzed. The serpentinized clasts show the greatest degree of variation in this regard (up to $18.9 \mathrm{ppm} \mathrm{Li}$ ) and also include a number of samples that approach the Li contents of depleted ultramafic
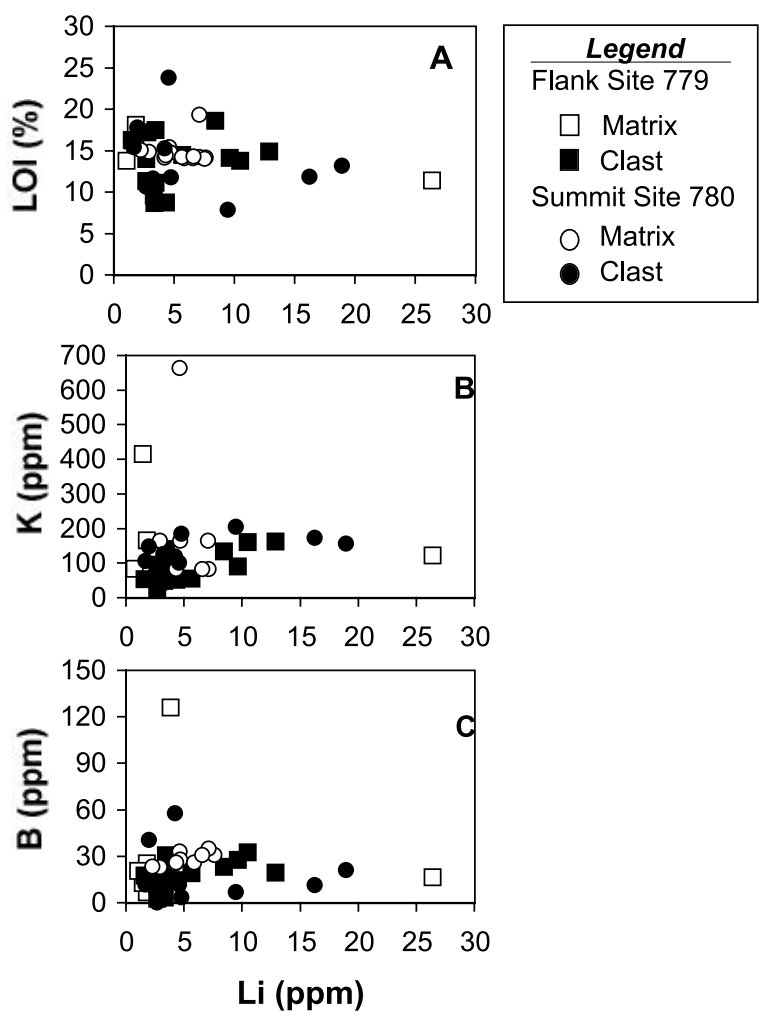

Figure 3. Plots of (a) Li concentrations versus LOI; (b) $\mathrm{Li}$ versus $\mathrm{K}$ concentrations; and (c) Li versus $\mathrm{B}$ concentrations for Leg 125 serpentinites. Additional data are from Benton et al. [2001] and Mattie and Ryan [1994]. 


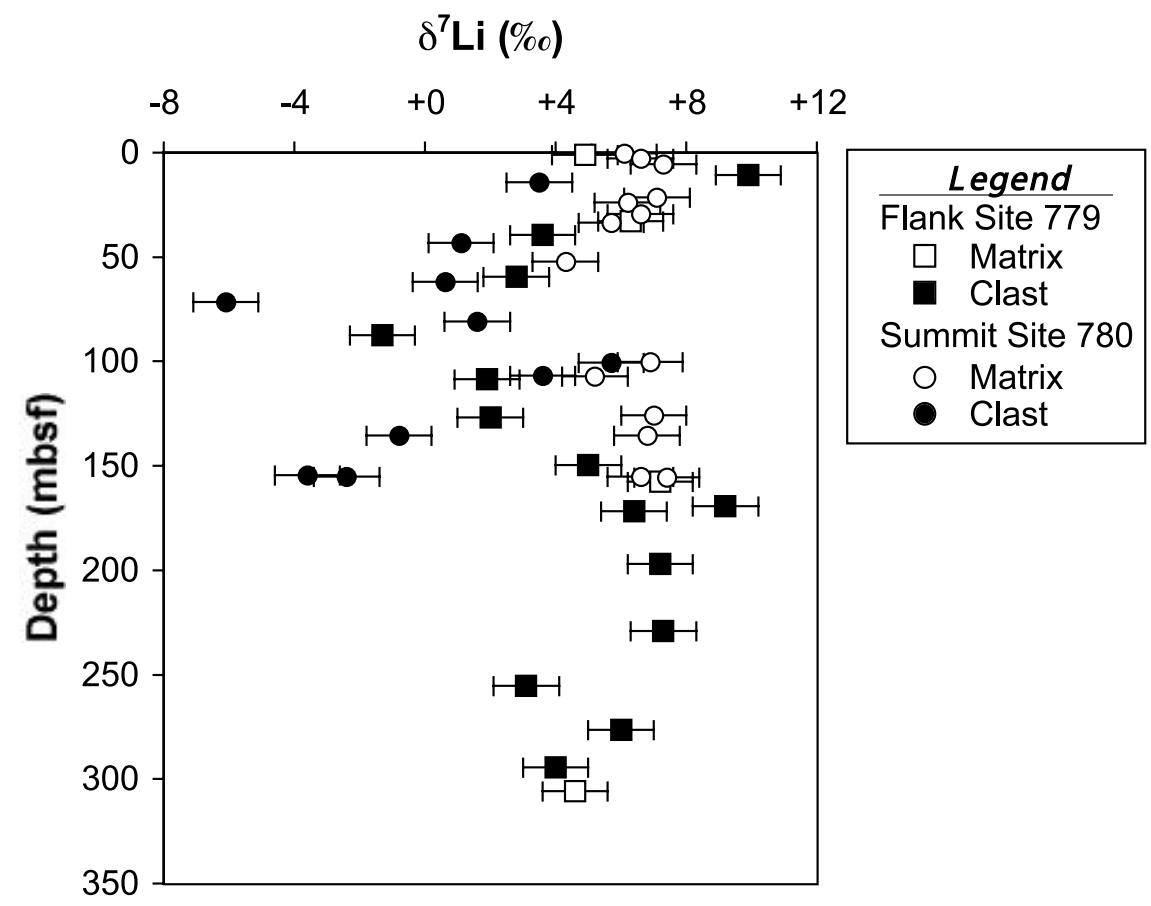

Figure 4. Plot of $\delta^{7} \mathrm{Li}$ for Leg 125 serpentinites versus depth in core.

rocks (i.e., $\sim 1-2 \mathrm{ppm}$ [see Ryan and Langmuir, 1987; Seitz and Woodland, 2000]). Lithium contents in the serpentinite muds are, by contrast, generally more consistent. It is possible that $\mathrm{Li}$ contents in matrix serpentines reflect in some way the equilibration of these $\mathrm{Mg}$-silicates with their associated pore waters: the upwelling, evolved slab-derived fluids at summit Site 780, and the seawater modified fluids found at flank Site 779 .

[15] Lithium partitions strongly into serpentine under low-temperature conditions as seen with other sheet silicates [Seyfried et al., 1984; Scambelluri et al., 2004]. Scambelluri et al. [2004] suggest a

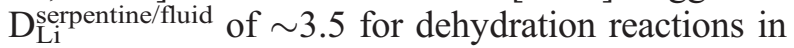
Alpine serpentinites, and the mud/fluid ratio of $\mathrm{Li}$ concentrations between the Site 779 muds and pore waters are consistent with such a D value. The much higher mud/fluid ratio for $\mathrm{Li}$ at Site 780 requires progressive removal of $\mathrm{Li}$ from the upwelling fluids into serpentine, producing very Li-depleted pore waters near the surface.

[16] The large variation in $\mathrm{Li}$ contents and $\delta^{7} \mathrm{Li}$ among the serpentinized clast samples argues against both simple models of equilibration with associated pore waters, or Rayleigh-style models for progressive removal. The ready uptake of Li by serpentine and other sheet silicates under lowtemperature $\left(<300^{\circ} \mathrm{C}\right)$ conditions [Seyfried et al., 1984, 1998] means that Li from vein fluids will be
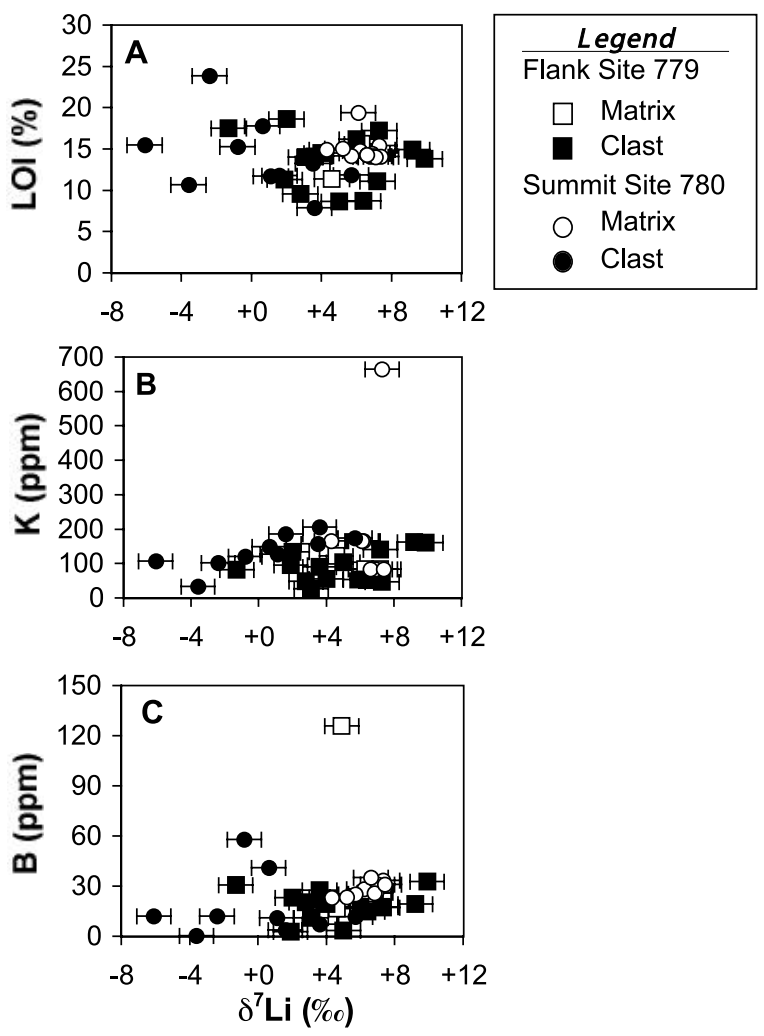

Figure 5. Plots of (a) $\delta^{7} \mathrm{Li}$ versus LOI; (b) $\delta^{7} \mathrm{Li}$ versus $\mathrm{K}$ concentrations; and (c) $\delta^{7} \mathrm{Li}$ versus $\mathrm{B}$ concentrations for Leg 125 serpentinites. Additional data are from Benton et al. [2001] and Mattie and Ryan [1994]. 


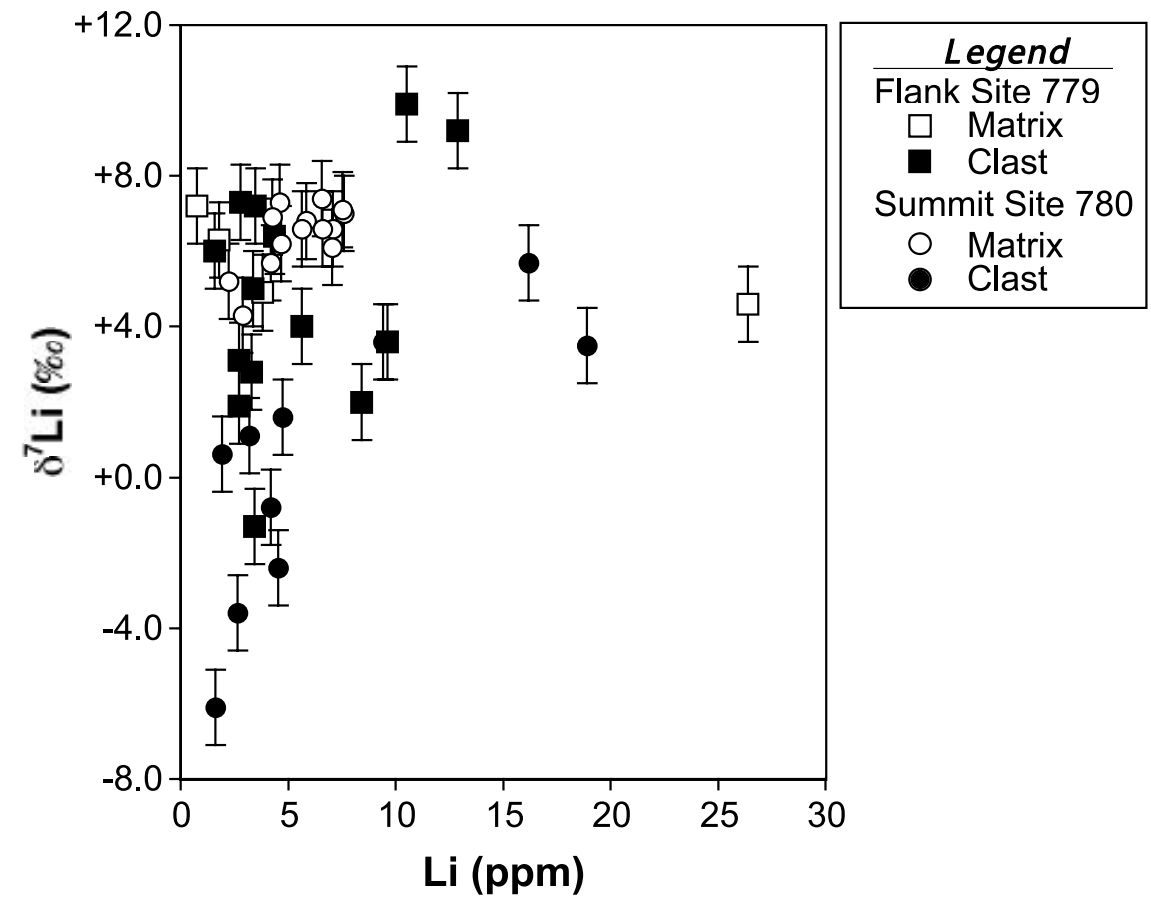

Figure 6. Plot of $\delta^{7} \mathrm{Li}$ versus Li concentrations for Leg 125 serpentinites.

incorporated rapidly by forming serpentine, creating a $\mathrm{Li}$ "concentration front" near the vein that diminishes rapidly with distance from the vein (Figure 7). High Li in serpentinized clasts probably indicates proximity to veins providing Li-enriched slab fluids, while low-Li serpentinized clasts indicate modification by waters from which $\mathrm{Li}$ has been removed during earlier fluid-rock exchanges. The result of these sorts of progressive exchanges should be markedly variable Li contents in serpentinized mantle rocks [e.g., Decitre et al., 2002].

[17] Lithium isotope systematics of the Conical serpentinites present a picture similar to that for Li abundances: the serpentinite matrix samples approach a mean $\delta^{7} \mathrm{Li}$ value of $+6 \%$, while the serpentinized clast samples show substantial variation, including values both lower and higher than the $\delta^{7} \mathrm{Li}$ range of the matrix samples. Lithium isotope ratios in the Leg 125 serpentinite clast and matrix materials are similar to a first order to those found in oceanic serpentinites by Decitre et al. [2002]. However, data for the associated pore waters, and B isotope results on these same samples document that the role of seawater in the development of the Leg 125 serpentinites is negligible [Benton et al., 2001; Mottl, 1992; Mottl et al., 2003]. The similarity in Li isotope results for the Mariana forearc serpentinites and marine serpentinites documents that, as in the oceans, the Leg 125 samples have interacted with fluid phases that had very high $\delta^{7} \mathrm{Li}[$ Chan and Edmond, 1988; Chan et al., 1992, 1994].

[18] Recently reported $\mathrm{Li}$ isotope data for pore waters from the South Chamorro serpentinite seamount (drilled during ODP Leg 195) point to exceptionally heavy signatures, with $\delta^{7} \mathrm{Li}$ values greater than $+40 \%$, suggesting fluid-serpentine fractionations of $\sim+30 \%$, assuming equilibrium exchange [see Savov et al., 2002]. $\delta^{7} \mathrm{Li}$ values like those of the serpentinite matrix samples reflect the mean Li isotopic signature imparted on the shallow mantle wedge by evolving slab fluids. This signature has a $\delta^{7} \mathrm{Li}$ value lower than reported averages for the altered crustal and sedimentary constituents of downgoing slabs, which range from +8 to $+14 \%$ o [e.g., Chan et al., 1992, 1994]. The $\delta^{7} \mathrm{Li}$ signatures of our serpentinites are also considerably lower than the $\delta^{7} \mathrm{Li}$ (up to $+20 \%$ ) inferred for the forearc reservoir from recent studies of eclogites and highgrade metamorphic suites, which indicate that deeply subducted materials may have very low $\delta^{7} \mathrm{Li}$ [Zack et al., 2003]. Specific data for the $\mathrm{Li}$ isotope ratios of Mariana trench sediments and altered crust are not available, so it is not clear if the serpentinites preserve $\mathrm{Li}$ that is different isotopically from the probable slab "infeed" to the Mariana subduction system. However, these serpentinites are consistent with the kinds of $\mathrm{Li}$ isotopic signatures encountered in lavas from the Mariana arc system, and in other island arcs 


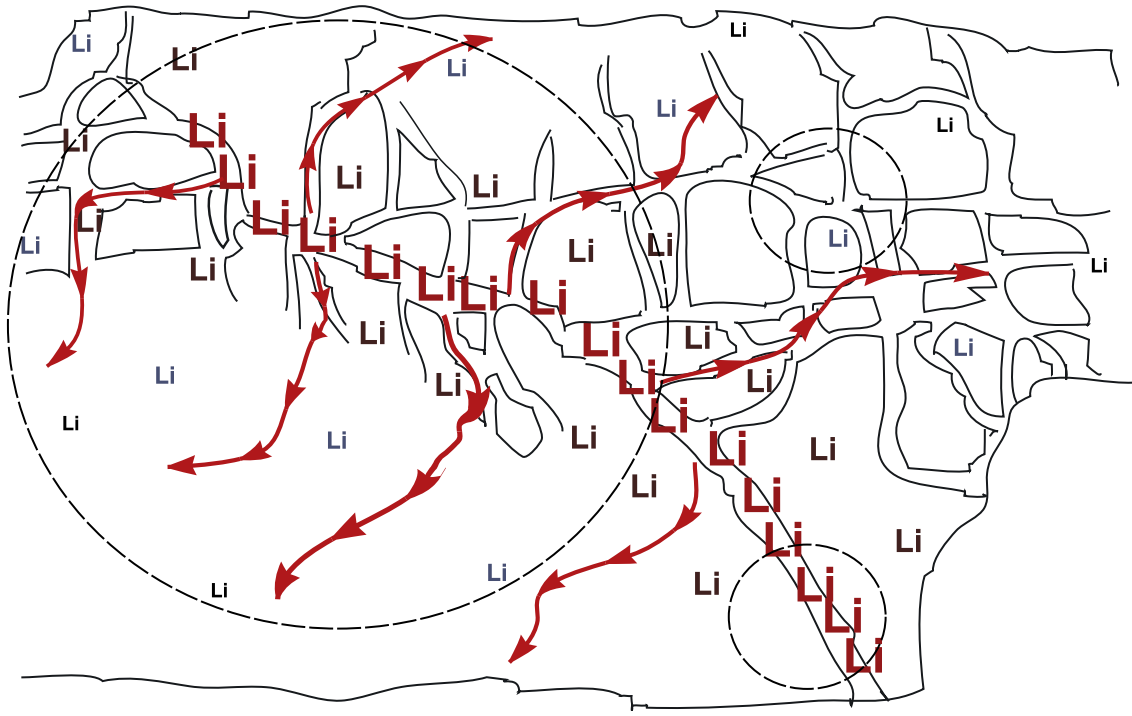

Figure 7. Sketch of a veined Mariana forearc serpentinite showing a likely pattern of Li distribution due to exchanges with vein fluids. Slab-derived fluids inject Li (red lettering), which is largely deposited in serpentine near the vein. Percolation of fluid outward from the vein forms serpentine with progressively lower Li content (brown to blue to black lettering). Subsequent fluid injections will overprint this pattern, producing serpentines with highly variable Li contents. Lithium isotope ratios in the forming serpentinite will vary on the basis of depths of fluid origin and the composition of the mantle, though high-Li samples will have higher $\delta^{7} \mathrm{Li}$ (see also Figure 8). Dashed circles overlain on the sketch represent the kind of sampling of this modified mantle that could occur during melting: small $\mathrm{F}$ melts will preferentially sample the most hydrated portions of the subarc mantle, but these portions may have either high or low $\delta^{7} \mathrm{Li}$. Melting at larger values of $\mathrm{F}$ will average greater volumes of mantle, producing lavas with intermediate (and relatively uniform) $\delta^{7} \mathrm{Li}$.

[Benton and Tera, 2000; Chan et al., 1999, 2001; Elliott et al., 1997; Moriguti and Nakamura, 1998; Tomascak et al., 2002].

\subsection{Sources of Li Isotope Heterogeneity in the Forearc Mantle}

[19] The Li isotopic diversity of the Leg 125 clasts is comparable to the in situ heterogeneity in $\mathrm{Li}$ isotopic compositions observed in seafloor serpentinites from the Southwest Indian Ridge [Decitre et al., 2002]. Our serpentinite clast data shows a broad correlation to $\mathrm{Li}$ content (i.e., higher $\delta^{7} \mathrm{Li}$ samples generally have higher Li abundances) and at the high end it overlaps the serpentinite mud data. However, there is a significant range in $\delta^{7} \mathrm{Li}$ at both the high-Li and low-Li ends of the array (i.e., samples with $>10 \mathrm{ppm} \mathrm{Li}$ have $\delta^{7} \mathrm{Li}$ of +3.5 to $+10 \%$, and samples with $<2 \mathrm{ppm} \mathrm{Li}$ have $\delta^{7} \mathrm{Li}$ of +6 to $-6 \%$; Figure 6). The pattern in Figure 6 implies that higher $\delta^{7} \mathrm{Li}$ clasts are produced via incorporation of slab-derived $\mathrm{Li}$ with a heavier $\mathrm{Li}$ isotopic composition, but the diversity in the data requires calling on a complex mixing process between the mantle wedge and slab-derived fluids of different compositions.
[20] Figure 8 describes one means for generating the $\delta^{7} \mathrm{Li}$ variation in the clasts. Any fluid derived from the slab will carry $\mathrm{Li}$ with a $\delta^{7} \mathrm{Li}$ value significantly higher than that of the slab, as all known solid/fluid fractionation processes for $\mathrm{Li}$ concentrate ${ }^{7} \mathrm{Li}$ in the hydrous fluid phase [Chan and Edmond, 1988; Chan et al., 1992, 1994]. The degree of $\mathrm{Li}$ abundance enrichment in slab-derived fluids will depend on the temperature of fluid release, as $\mathrm{D}_{\mathrm{Li}}^{\text {solid/fluid }}$ is strongly temperature dependent between 100 and $400^{\circ} \mathrm{C}$, with Li becoming more soluble where temperatures are higher [Seyfried et al., 1984, 1998]. As well, the $\delta^{7} \mathrm{Li}$ of slab fluids will become lower as the temperatures of fluid generation increase, because $\alpha_{\mathrm{Li}}^{\text {fluid/serpentine }}$ declines with increasing temperature. Thus fluids released from the slab at relatively low temperatures (i.e., at shallow slab depths) will have lower $\mathrm{Li}$ contents, but higher $\delta^{7} \mathrm{Li}$, while fluids released at higher temperatures (i.e., greater depths) will have higher Li contents and lower $\delta^{7} \mathrm{Li}$. Progressive exchanges between such slab fluids and mantle rock in the shallow forearc will produce serpentinites with variable Li concentrations (due to the high $\mathrm{D}_{\mathrm{Li}}^{\text {serpentine/fluid }}$ [Scambelluri et al., 2004]). Lithium isotope ratios in the forming 


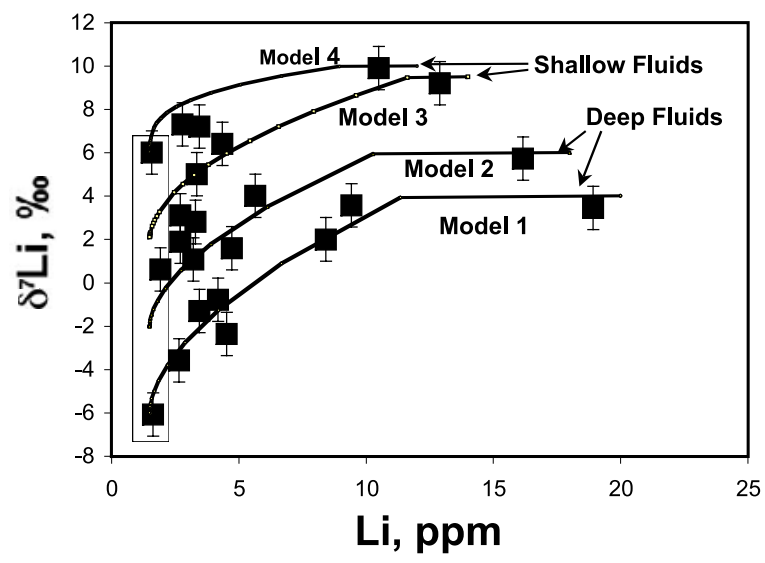

Figure 8. Plot of $\delta^{7} \mathrm{Li}$ versus $\mathrm{Li}$ concentrations for the Leg 125 serpentinized clast samples. The four trend lines represent possible serpentine compositions developed during progressive fluid/rock serpentinization reactions with fluids derived from deeper (Models 1 and 2) and shallower (Models 3 and 4) portions of the slab. Serpentine compositions were calculated incrementally using the equilibrium fluid/rock exchange equation [Nabelek, 1987, equation (3)]: $\mathrm{C}_{\mathrm{r}}^{\mathrm{f}}=\left(\mathrm{C}_{\mathrm{r}}^{\mathrm{i}}+\right.$ $\left.N_{\mathrm{w}}^{\mathrm{i}}\right) /\left(\mathrm{D}_{\mathrm{s}}^{1} \mathrm{~N}+1\right)$ for $\mathrm{Li}$ concentrations and $\mathrm{R}_{\mathrm{r}}^{\mathrm{f}}=\left[\left(\left(\mathrm{R}_{\mathrm{r}}^{\mathrm{i}}+\right.\right.\right.$ $\left.\left.1000)+N\left(R_{w}^{i}+1000\right)\right) /\left(\alpha_{S}^{1} N+1\right)\right]-1000$ for $\delta^{7} \mathrm{Li}$ values. $C_{r}$ represents concentrations in the rock, $C_{w}$ is concentrations in the fluids, $\mathrm{R}_{\mathrm{r}}$ is the $\delta^{7} \mathrm{Li}$ of the rock, and $\mathrm{R}_{\mathrm{W}}$ is the $\delta^{7} \mathrm{Li}$ of the fluid; $\mathrm{D}_{\mathrm{s}}^{1}$ is the fluid/solid distribution coefficient for Li (set at 3.5 [Scambelluri et al., 2004]), and $\alpha_{\mathrm{s}}^{1}$ is the Li isotope fractionation factor (set at 1.015, assuming higher temperatures than encountered during exchanges on the seafloor [e.g., Chan et al., 1992]). Initial fluid Li concentrations and isotope ratios were estimated on the basis of the values necessary to produce the high-Li, high- $\delta^{7} \mathrm{Li}$ samples along each trend. Fluid/rock ratios begin at 1.5 for the deep fluid trends and at 2.3 for the shallow fluid trends. The Li concentration of the mantle is set at $1.5 \mathrm{ppm}$ [Ryan and Langmuir, 1987; Seitz and Woodland, 2000], while mantle $\delta^{7} \mathrm{Li}$ values were selected to best approximate the trends of our data. Fluid/rock ratios were reduced with each increment calculated to reflect the incorporation of fluids into forming serpentines; increment sizes were kept small so as to approximate continuous fluid/rock exchange during serpentine formation. The large range of $\delta^{7} \mathrm{Li}$ in both the high-Li and low-Li serpentinite clasts necessitates multiple fluid/ rock exchange trajectories with fluids of different initial $\delta^{7} \mathrm{Li}$ and lithium concentrations, and a mantle that is already zoned in terms of $\mathrm{Li}$ isotopic composition.

serpentinites will be related to the original $\delta^{7} \mathrm{Li}$ values of the fluid and the mantle, and to the isotope fractionation factor for $\mathrm{Li}$ between serpentine and fluid (i.e., $\alpha_{\mathrm{Li}}^{\text {fluid/serpentine }}$ ) at the temperature (i.e., depth) of exchange.
[21] The calculated fluid-rock exchange trajectories on Figure 8 reflect progressive serpentine formation due to the reaction of slab-derived fluids with the forearc mantle wedge. No single trajectory can explain the range of $\mathrm{Li}$ abundances and $\delta^{7} \mathrm{Li}$ values observed in our Leg 125 clasts. However, a series of trajectories, reflecting exchanges with fluids possessing variable $\mathrm{Li}$ concentrations and $\delta^{7} \mathrm{Li}$, consistent with the signatures of fluids released from the slab at different depths, approximates the observed variation, assuming the mantle possesses significant variability in its $\mathrm{Li}$ isotopic signature before exchange (i.e., that mantle horizons already existed with $\delta^{7} \mathrm{Li}$ from $+6 \%$ o to $-6 \%$ ).

[22] Nishio et al. [2004] has reported $\delta^{7} \mathrm{Li}$ signatures for mantle xenoliths ranging from +6 to $-17 \%$, and attributes the lower values to exchanges with distinct metasomatizing agents derived from slab materials subducted to great depths. Zack et al. [2003] also infers the release of slab fluids at great depths to produce eclogites with $\delta^{7} \mathrm{Li}$ of $-11 \%$. A low- $\delta^{7} \mathrm{Li}$, deep-derived slab fluid percolating upward (i.e., down temperature) along the slab-mantle interface could react at shallower depths with upper mantle materials that have $\delta^{7} \mathrm{Li} \approx+3 \%$ to produce solids with lower $\delta^{7} \mathrm{Li}$, because the value of $\alpha_{\mathrm{Li}}^{\text {fluid/solid }}$ at the depth of this reaction will be larger than at the depth from which the fluid originated. Exchanges between deep-derived slab fluids and upper mantle materials in the forearc may be a viable mechanism for creating zones of variable $\delta^{7} \mathrm{Li}$ in the mantle.

\subsection{Implications for $\mathrm{Li}$ Isotope Systematics in Volcanic Arcs}

[23] Significant heterogeneity in radiogenic isotopic signatures (i.e., ${ }^{87} \mathrm{Sr} /{ }^{86} \mathrm{Sr},{ }^{143} \mathrm{Nd} /{ }^{144} \mathrm{Nd}$, $\mathrm{U}-\mathrm{Th}-\mathrm{Pb})$ is well documented in mantle rocks [Nishio et al., 2004; Reisberg and Zindler, 1986; Reisberg et al., 1989; and references therein). Variations in radiogenic isotope ratios within an ultramafic massif can be as great or greater than the total isotopic variation observed in mantle-derived volcanic rocks [see Reisberg et al., 1989, Figure 10]. The range of $\delta^{7} \mathrm{Li}$ values in our Leg 125 clasts is larger than the total $\mathrm{Li}$ isotopic variation among all igneous rocks thus far examined. The highest values in our suite (at $+9.9 \%$ ) are only slightly lower than the highest $\delta^{7} \mathrm{Li}$ ever reported in an arc, $+11.2 \%$ in the Panama arc segment of Central America [Tomascak et al., 2000]. So, as with radiogenic isotope systems, Li isotope ratios may record fine-scale geochemical variations in mantle 
source materials. This variation arises from multistage additions of exotic (in this case, slab-derived) components, and isotopic exchange under multiple $\mathrm{P}-\mathrm{T}$ conditions.

[24] Modeling the Li isotope systematics of subduction zones as a simple mixture of slab-derived and mantle-derived $\mathrm{Li}$, as is often done in examining isotopic variations in arcs, is problematic because of the complex manner in which slab lithium is added to the subarc mantle, and the significant redistribution of $\mathrm{Li}$ that occurs as a result of such additions. Straub and Layne [2002] explained unusually high $\delta^{11} \mathrm{~B}$ values in tephra glasses from the Izu arc through mechanical inputs to subarc source regions of forearc derived, high $\delta^{11} \mathrm{~B}$ serpentinized mantle materials via drag convection [e.g., Tatsumi, 1986]. Our Li isotope results for Conical serpentinites indicate that such a model is a permissible explanation of observed $\mathrm{Li}$ isotope systematics in the Mariana arc, and in other "mature" subduction systems where the observed $\mathrm{Li}$ isotopic variation is limited [e.g., Benton and Tera, 2000; Chan et al., 1999, 2001; Tomascak et al., 2002]. However, arcs in which $\mathrm{Li}$ isotopic compositions both heavier and lighter than those in the Mariana arc system are encountered (e.g., Panama [Tomascak et al., 2000]) cannot be easily explained in this manner.

[25] Perhaps the best model for understanding the $\mathrm{Li}$ isotopic diversity that results from slab inputs, and relating this diversity to the $\mathrm{Li}$ isotopic signatures of arcs, is to call upon the "plum pudding" type models used to explain mantle reservoir mixing and magmatic sampling at ocean islands and seamounts [Allègre and Turcotte, 1986; Batiza and Vanko, 1984; Phipps Morgan and Morgan, 1999]. Vein serpentine and highly hydrated ultramafic materials near veins will have high Li and variably high $\delta^{7} \mathrm{Li}$, while the variably serpentinized mantle between zones of veining will have lower $\mathrm{Li}$ concentrations, and $\delta^{7} \mathrm{Li}$ values ranging from those of typical upper mantle (i.e., MORB-like) to exceptionally low values, perhaps reflecting exchanges with deep slab fluids (Figure 7). If these complexly modified mantle materials convect to depth and became part of a subarc mantle source, both the hydrated higher $\delta^{7} \mathrm{Li}$ materials, and the hydrated low $-\delta^{7} \mathrm{Li}$ mantle rocks will be more liable to melt. Thus, at low values of melt fraction $(\mathrm{F})$, either high- $\delta^{7} \mathrm{Li}$ or low- $\delta^{7} \mathrm{Li}$ melts (or melts consisting of mixtures of these end-member materials, dominated by the higher Li abundance end-member) might occur, as initial melts will be dominated by hydrated mantle components. As F increases, more of the mantle source melts, and proportionally less hydrated mantle material will be sampled by melting, which should shift the mean $\delta^{7} \mathrm{Li}$ of the forming magmas away from extreme values, and closer to an average value for upper mantle rocks. In "mature" arcs such as the Mariana subduction system, the Kuril arc and others, values for $\mathrm{F}$ are generally high, so $\delta^{7} \mathrm{Li}$ approaches MORB-like values [Benton and Tera, 2000; Tomascak et al., 2002]. In anomalous arc settings, such as Panama, [e.g., Defant et al., 1991; Tomascak et al., 2000] magmatism is more sporadic, $\mathrm{F}$ is necessarily lower, and $\mathrm{Li}$ isotope ratios may thus approach some of the more extreme values encountered in the Mariana forearc mantle.

\subsection{Comparisons to B Isotope Systematics in Arcs and Implications for Li Isotopes as a "Tool" in Studies of Subduction Zones}

[26] Given the differences in their solid-fluid behaviors in forearc settings, the $\mathrm{B}$ and $\mathrm{Li}$ isotopic systems provide distinctly different types of information about the slab-mantle exchange processes occurring during subduction. Boron abundances and $\mathrm{B}$ isotopes provide a fingerprint of the slab fluid input, while $\mathrm{Li}$ abundances and $\mathrm{Li}$ isotopes provide insights into how this fluid input modifies and hybridizes the subarc mantle. The "decoupling" of $\mathrm{Li}$ isotopes and $\mathrm{B} / \mathrm{Be}$ systematics in Panama arc lavas reported by Tomascak et al. [2000] is consistent with the behavioral characteristics of these elements: boron tracks slab fluid inputs exclusively, while Li "sees" subductiongenerated mantle heterogeneity beneath the Panamanian arc, and not just the signature of the most recent fluid inputs (Figure 9). Mantle heterogeneity beneath volcanic arcs is evident only where the "slab effect" is minimized [see Edwards et al., 1993; Lin et al., 1990]. In the case of Li, preserved mantle heterogeneity may be related to past slabmantle exchange events, so presumably Li isotopic variations in arc lavas will only be identifiable in the case of "dying" arcs, where subduction rates and associated slab fluid inputs have diminished.

\section{Conclusions}

[27] Serpentinite muds from the Mariana forearc have $\mathrm{Li}$ isotope ratios lower overall than many probable slab materials, but similar to Mariana arc lavas. The associated serpentinized ultramafic clasts preserve heterogeneous $\delta^{7} \mathrm{Li}$ signatures, reflecting a complex history of exchanges between 


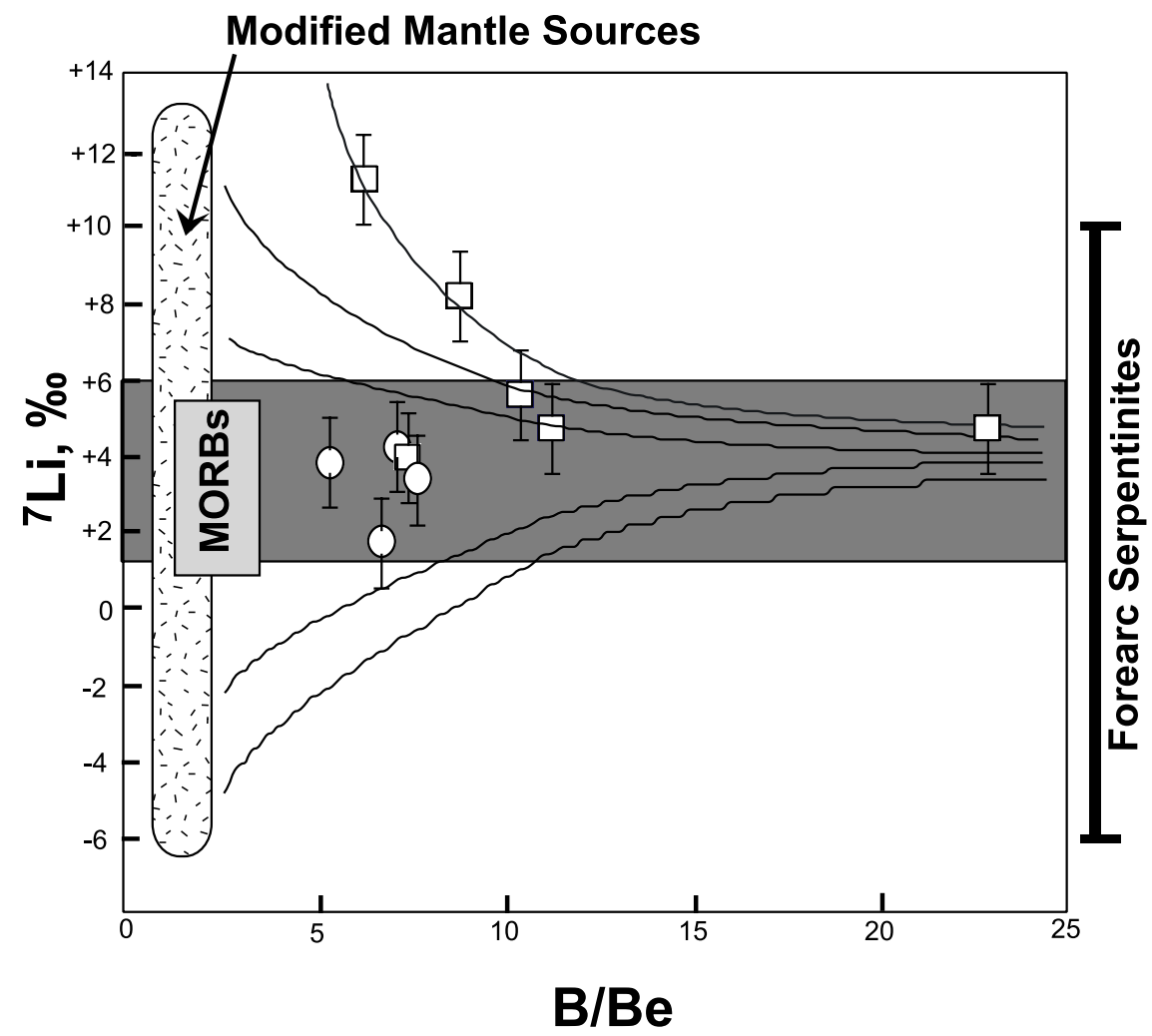

Figure 9. Plot of $\delta^{7} \mathrm{Li}$ versus $\mathrm{B} / \mathrm{Be}$ for arc lavas. The darkly shaded field across the diagram represents the combined $\delta^{7} \mathrm{Li}$ arc data sets of Chan et al. [1999, 2001] and Tomascak et al. [2002], which constitute most of the available data on "normal" arcs, and overlaps entirely with the range for MORBs (labeled [Tomascak and Langmuir, 1999]). The symbols represent Old Group (squares) and Young Group (circles) arc lavas from Panama [Tomascak et al., 2000]. The range of $\delta^{7} \mathrm{Li}$ for the Mariana forearc serpentinites is shown by the large bracket to the right of the plot. The stippled vertical field represents the range of possible $\delta^{7} \mathrm{Li}$ signatures developed in the mantle wedge over time via slab fluid exchange, and the curves represent hypothetical mixing arrays between these mantle reservoirs and slab fluid, which has high $\mathrm{B} / \mathrm{Be}$, and (in most arcs) relatively MORB-like $\delta^{7} \mathrm{Li}$.

Li-bearing, slab-derived fluids and the forearc mantle wedge. Melting beneath arcs mixes Lienriched mantle horizons with unaltered mantle rocks, producing $\delta^{7} \mathrm{Li}$ values only modestly different from those of MORBs. Only in anomalous circumstances can the $\mathrm{Li}$ isotope heterogeneity of the mantle be observed in the compositions of arc lavas.

\section{Acknowledgments}

[28] This research used samples and data provided by the Ocean Drilling Program (ODP). ODP is sponsored by the U.S. National Science Foundation (NSF) and participating countries under management of Joint Oceanographic Institutions (JOI), Inc. Funding for this work was provided by the Department of Terrestrial Magnetism (DTM) at the Carnegie Institution of Washington, an NSF Postdoctoral Fellowship to L.D.B., NSF grant OCE-9907736 to J.G.R., and a GSA Graduate Student research award to I.P.S. Thanks much to Fouad Tera, Steve Shirey, Rick Carlson, and Tim Mock at DTM for their generous support of this project, and for their support of J.G.R. in 2000 during his sabbatical, when part of the work presented here was completed. In addition, L.D.B wishes to thank Janet Haggerty for her support of an early portion of this work in association with L.D.B.'s doctoral dissertation. Thanks in particular to Paul Tomascak, for his thoughtful (and witty) discussions on Li geochemistry and guidance in learning the chemical and mass spectrometric techniques for $\mathrm{Li}$ isotopic analysis.

\section{References}

Allègre, C. J., and D. L. Turcotte (1986), Implications of a two-component marble-cake mantle, Nature, 323, 123127.

Batiza, R., and D. Vanko (1984), Petrology of young Pacific seamounts, J. Geophys. Res., 89, 1235-1260.

Benton, L. D. (1997), Origin and evolution of serpentine seamount fluids, Mariana and Izu-Bonin forearcs: Implications for the recycling of subducted material, Ph.D. dissertation, Univ. of Tulsa, Tulsa, Okla.

Benton, L. D., and F. Tera (2000), Lithium isotope systematics of the Marianas revisited, Goldschmidt J. Conf. Abstr., 5, 210.

Benton, L. D., J. G. Ryan, and F. Tera (2001), Boron isotope systematics of slab fluids as inferred from a serpentinite 
seamount, Mariana forearc, Earth Planet. Sci. Lett., 187, 273-282.

Brenan, J. M., E. Neroda, C. C. Lindstrom, H. F. Shaw, F. J. Ryerson, and D. L. Phinney (1998a), Behaviour of boron, beryllium and lithium during melting and crystallization: Constraints from mineral-melt partitioning experiments, Geochim. Cosmochim. Acta, 62, 2129-2141.

Brenan, J. M., F. J. Ryerson, and H. F. Shaw (1998b), The role of aqueous fluids in the slab-to-mantle transfer of boron, beryllium, and lithium during subduction: Experiments and models, Geochim. Cosmochim. Acta, 62, 3337-3347.

Chan, L.-H., and J. M. Edmond (1988), Variation of lithium isotope composition in the marine environment: A preliminary report, Geochim. Cosmochim. Acta, 52, 1711-1717.

Chan, L.-H., J. M. Edmond, G. Thompson, and K. Gillis (1992), Lithium isotopic composition of submarine basalts: Implications for the lithium cycle in the oceans, Earth Planet. Sci. Lett., 108, 151-160.

Chan, L.-H., J. M. Gieskes, C.-F. You, and J. M. Edmond (1994), Lithium isotope geochemistry of sediments and hydrothermal fluids of the Guaymas Basin, Gulf of California, Geochim. Cosmochim. Acta, 58, 4443-4454.

Chan, L.-H., W. P. Leeman, and C.-F. You (1999), Lithium isotopic composition of Central American volcanic arc lavas: Implications for modification of the sub-arc mantle by slabderived fluids, Chem. Geol., 160, 255-280.

Chan, L.-H., W. P. Leeman, and C.-F. You (2001), Lithium isotopic composition of Central American volcanic arc lavas: Implications for modification of the sub-arc mantle by slabderived fluids: Correction, Chem. Geol., 182, 293-300.

Class, C., D. M. Miller, S. L. Goldstein, and C. H. Langmuir (2000), Distinguishing melt and fluid subduction components in Umnak Volcanics, Aleutian Arc, Geochem. Geophys. Geosyst., 1, Paper number 1999GC000010.

Decitre, S., E. Deloule, L. Reisberg, R. James, P. Agrinier, and C. Mével (2002), Behavior of $\mathrm{Li}$ and its isotopes during serpentinization of oceanic peridotites, Geochem. Geophys. Geosyst., 3(1), 1007, doi:10.1029/2001GC000178.

Defant, M. J., L. F. Clark, R. H. Stewart, M. S. Drummond, J. Z. de Boer, R. C. Maury, H. Bellon, T. E. Jackson, and J. F. Restrepo (1991), Andesite and dacite genesis via contrasting processes: The geology and geochemistry of El Valle Volcano, Panama, Contrib. Mineral. Petrol., 106, 309-324.

Edwards, C. M. H., J. D. Morris, and M. F. Thirlwall (1993), Separating mantle from slab signatures in arc lavas using $\mathrm{B} / \mathrm{Be}$ and radiogenic isotope systematics, Nature, 362, 530-533.

Elliott, T., T. Plank, A. Zindler, W. White, and B. Bourdon (1997), Element transport from subducted slab to juvenile crust at the Mariana arc, J. Geophys. Res., 102, 14,99115,019 .

Fryer, P. (1992), A synthesis of Leg 125 drilling of serpentine seamounts on the Mariana and Izu-Bonin forearcs, Proc. Ocean Drill. Program Sci. Results, 125, 593-614.

Fryer, P. (2002), Recent studies of serpentinite occurrences in the oceans: Mantle-ocean interactions in the plate tectonic cycle, Chem. Erde, 62, 257-302.

Fryer, P., and G. J. Fryer (1987), Origins of nonvolcanic seamounts in a forearc environment, in Seamounts, Islands, and Atolls, Geophys. Monogr. Ser., vol. 43, edited by B. H. Keating et al., pp. 61-69, Washington, D. C.

Fryer, P., E. L. Ambos, and D. M. Hussong (1985), Origin and emplacement of Mariana forearc seamounts, Geology, 13, 774-777.

Fryer, P., K. L. Saboda, L. B. Johnson, M. E. Mackay, G. F. Moore, and P. Stoffers (1990), Conical Seamount: Sea-
MARK II, Alvin submersible, and seismic reflection studies, Proc. Ocean Drill. Program Initial Rep., 125, 69-80.

Guggino, S., I. P. Savov, and J. G. Ryan (2002), Light element systematics of metamorphic clasts from ODP Legs 125 and 195, South Chamorro and Conical Seamounts, Mariana forearc, Eos Trans. AGU, 83(19), Spring Meet. Suppl., Abstract V51A-08.

Haggerty, J. A. (1991), Evidence from fluid seeps atop serpentine seamounts in the Mariana forearc: Clues for emplacement of the seamounts and their relationship to forearc tectonics, Mar. Geol., 102, 293-309.

Haggerty, J. A., and S. Chaudhuri (1992), Strontium isotopic composition of the interstitial waters from Leg 125: Mariana and Bonin forearcs, Proc. Ocean Drill. Program Sci. Results, 125, 397-400.

Heling, D., and A. Schwarz (1992), Iowaite in serpentinite muds at Sites 778, 779, 780 and 784: A possible cause for the low chlorinity of pore waters, Proc. Ocean Drill. Program Sci. Results, 125, 313-323.

Hussong, D. M., and P. Fryer (1985), Fore-arc tectonics in the Northern Mariana Arc, in Formation of Active Ocean Margins, edited by N. Nasu et al., pp. 273-290, Terra Sci., Tokyo.

Ishikawa, T., and E. Nakamura (1994), Origin of the slab component in arc lavas from across-arc variation of $\mathrm{B}$ and $\mathrm{Pb}$ isotopes, Nature, 370, 205-208.

Kepezhinskas, P., and M. J. Defant (1996), Contrasting styles of mantle metasomatism above subduction zones: Constraints from ultramafic xenoliths, in Kamchatka, in Subduction: Top to Bottom, Geophys. Monogr. Ser., vol. 96, edited by G. E. Bebout et al., pp. 307-314, AGU, Washington, D. C.

Lagabrielle, Y., A.-M. Karpoff, and J. Cotton (1992), Mineralogical and geochemical analyses of sedimentary serpentinites from Conical Seamount (Hole 778A): Implications for the evolution of serpentine seamounts, Proc. Ocean Drill. Program Sci. Results, 125, 325-342.

Lin, P. N., R. J. Stern, J. D. Morris, and S. H. Bloomer (1990), Nd- and Sr-isotopic compositions of lavas from the northern Mariana and southern Volcano arcs: Implications for the origin of island arc melts, Contrib. Mineral. Petrol., 105, $381-392$

Maekawa, H., M. Shozui, T. Ishii, K. L. Saboda, and Y. Ogawa (1992), Metamorphic rocks from the serpentine seamounts in the Mariana and Izu-Ogasawara forearcs, Proc. Ocean Drill. Program Sci. Results, 125, 415-430.

Maekawa, H., P. Fryer, and A. Ozaki (1995), Incipient blueschist-facies metamorphism in the active subduction zone beneath the Mariana forearc, in Active Margins and Marginal Basins of the Western Pacific, Geophys. Monogr. Ser, vol. 88, edited by B. Taylor and J. Natland, pp. 281-289, AGU, Washington, D. C.

Mattie, P. D., and J. G. Ryan (1994), Boron and alkaline element systematics in serpentinites from Holes 779A, 780C, and 784A, ODP Leg 125 describing fluid-mediated slab additions, Eos Trans. AGU, 75, Fall Meet. Suppl., F352.

Miller, D. M., C. H. Langmuir, and S. L. Goldstein (1994), Cerium/lead and lead isotope ratios in arc magmas and the enrichment of lead in the continents, Nature, 368, 514-520.

Moriguti, T., and E. Nakamura (1998), Across-arc variation of $\mathrm{Li}$ isotopes in lavas and implications for crust/mantle recycling at subduction zones, Earth Planet. Sci. Lett., 163, $167-$ 174.

Morris, J. D., and J. G. Ryan (2003), Subduction zone processes and implications for changing composition of the upper and lower mantle, in Treatise on Geochemistry, edited 
by R. Carlson, chap. 2, pp. 451-470, Elsevier Sci., New York.

Mottl, M. J. (1992), Pore waters from serpentine seamounts in the Mariana and Izu-Bonin Forearcs, Leg 125: Evidence for volatiles from the subducting slab, Proc. Ocean Drill. Program Sci. Results, 125, 373-385.

Mottl, M. J., S. C. Komor, P. Fryer, and C. L. Moyer (2003), Deep-slab fluids fuel extremophilic Archaea on a Mariana forearc serpentinite mud volcano: Ocean Drilling Program Leg 195, Geochem. Geophys. Geosyst., 4(11), 9009, doi:10.1029/2003GC000588.

Nabelek, P. I. (1987), General equations for modeling fluid/ rock interaction using trace elements and isotopes, Geochim. Cosmochim. Acta, 51, 1765-1769.

Nishio, Y., S. Nakai, J. Yamamoto, H. Sumino, T. Matsumoto, V. S. Prikhod'ko, and S. Arai (2004), Lithium isotopic systematics of the mantle-derived ultramafic xenoliths: Implications for EM1 origin, Earth Planet. Sci. Lett., 217, 245-261.

Pearce, J. A., and D. W. Peate (1995), Tectonic implications of the composition of volcanic arc magmas, Annu. Rev. Earth Planet. Sci., 23, 251-285.

Phipps Morgan, J., and W. J. Morgan (1999), Two-stage melting and the geochemical evolution of the mantle: A recipe for mantle plum-pudding, Earth Planet. Sci. Lett., 170, $215-$ 239.

Plank, T., and C. H. Langmuir (1993), Tracing trace element from sediment input to volcanic output at subduction zones, Nature, 362, 739-742.

Reisberg, L., and A. Zindler (1986), Extreme isotopic variations in the upper mantle: Evidence from Ronda, Earth Planet. Sci. Lett., 81, 29-45.

Reisberg, L., A. Zindler, and E. Jagoutz (1989), Further Sr and $\mathrm{Nd}$ isotopic results from peridotites of the Ronda ultramafic complex, Earth Planet. Sci. Lett., 96, 161-180.

Ryan, J. G., and C. H. Langmuir (1987), The systematics of lithium abundances in young volcanic rocks, Geochim. Cosmochim. Acta, 51, 1727-1741.

Saboda, K. L., P. Fryer, and H. Maekawa (1992), Metamorphism of ultramafic clasts from Conical Seamount: Sites 778, 779, and 780, Proc. Ocean Drill. Program Sci. Results, $125,431-443$.

Savov, I. P. (2004), Petrology and geochemistry of subductionrelated rocks from the Mariana arc-basin system, Ph.D. dissertation, 355 pp., Univ. of South Fla., Tampa.

Savov, I. P., J. G. Ryan, P. Mattie, and J. Schijf (2000), Fluidmobile element systematics of ultramafic xenoliths from the Izu-Bonin-Mariana forearc: Implications for the chemical cycling in subduction zones, Eos Trans. $A G U, 81(48)$, Fall Meet. Suppl., Abstract V21C-02.

Savov, I. P., J. G. Ryan, L. Chan, M. D’Antonio, M. Mottl, P. Fryer, and ODP Leg 195 Sci. Party (2002), Geochem- istry of serpentinites from the S. Chamorro Seamount, ODP Leg 195, Site 1200, Mariana Forearc-Implications for recycling at subduction zones, Goldschmidt J. Conf. Abstr., 7, A670.

Scambelluri, M., O. Müntener, L. Ottolini, T. T. Pettke, and R.Vannucci (2002), The fate of $\mathrm{B}, \mathrm{Cl}$, and $\mathrm{Li}$ in the subducted oceanic mantle and in the antigorite breakdown fluids, Earth Planet. Sci. Lett., 204, 217-234.

Seitz, H. M., and A. B. Woodland (2000), The distribution of lithium in peridotitic and pyroxenitic mantle lithologies: An indicator of magmatic and metasomatic processes, Chem. Geol., 166, 47-64.

Seyfried, W. E., Jr., D. R. Janecky, and M. J. Mottl (1984), Alteration of the oceanic crust: Implications for the geochemical cycles of lithium and boron, Geochim. Cosmochim. Acta, 48, 557-569.

Seyfried, W. E., Jr., X. Chen, and L.-H. Chan (1998), Trace element mobility and lithium isotope exchange during hydrothermal alteration of seafloor weathered basalt: An experimental study at $350^{\circ} \mathrm{C}, 500$ bars, Geochim. Cosmochim. Acta, 62, 949-960.

Spivack, A. J., and J. M. Edmond (1987), Boron isotope exchange between seawater and the oceanic crust, Geochim. Cosmochim. Acta, 51, 1033-1043.

Straub, S. M., and G. D. Layne (2002), The systematics of boron isotopes in Izu arc front volcanic rocks, Earth Planet. Sci. Lett., 198, 25-39.

Tatsumi, Y. (1986), Formation of the volcanic front in subduction zones, Geophys. Res. Lett., 13, 717-720.

Tomascak, P. B., and C. H. Langmuir (1999), Lithium isotope variability in MORB, Eos Trans. $A G U, 80(46)$, Fall Meet. Suppl., F1086-F1087.

Tomascak, P. B., R. W. Carlson, and S. B. Shirey (1999a), Accurate and precise determination of $\mathrm{Li}$ isotopic compositions by multi-collector sector ICP-MS, Chem. Geol., 158, $145-154$

Tomascak, P. B., F. Tera, R. T. Helz, and R. J. Walker (1999b), The absence of lithium isotope fractionation during basalt differentiation: New measurements by multi-collector sector ICP-MS, Geochim. Cosmochim. Acta, 63, 907-910.

Tomascak, P. B., J. G. Ryan, and M. J. Defant (2000), Lithium isotope evidence for light element decoupling in the Panama sub-arc mantle, Geology, 28, 507-510.

Tomascak, P. B., E. Widom, L. D. Benton, S. L. Goldstein, and J. G. Ryan (2002), The control of lithium budgets in island arcs, Earth Planet. Sci. Lett., 196, 227-238.

Zack, T., P. B. Tomascak, R. L. Rudnick, C. Dalpe, and W. F. McDonough (2003), Extremely light Li in orogenic eclogites: The role of isotope fractionation during dehydration in subducted oceanic crust, Earth Planet. Sci. Lett., 208, $279-290$ 